\title{
ЗАСТОСУВАННЯ КІБЕРФІЗИЧНИХ БІОСЕНСОРНИХ ТА ІМУНОСЕНСОРНИХ СИСТЕМ
}

\author{
В. П. Марценюк, А. С. Сверстюк ${ }^{1}$, Т. В. Бігуняк ${ }^{1}$, \\ А. В. Павлишин ${ }^{1}$, О. М. Мочульська ${ }^{1}$ \\ Університет Бєльсько-Бяли, Республіка Польща
${ }^{1}$ Двнз «Тернопільський державний медичний університет імені I. Я. Горбачевського \\ мОЗ України»
}

\begin{abstract}
У роботі проведено огляд кіберфрізичних біосенсорних та імуносенсорних систем, що є новим поколінням інфрормаційно-вимірювальних систем із використанням у конструкції біологічних матеріалів, які забезпечують їх високу селективність. Проведена класифікація досліджуваних систем відносно чутливих елементів і можливості використанням різних режимів фрізико-хімічного перетворення вимірювальної величини. Розглянуто такі види кіберфізичних біосенсорних та імуносенсорних систем: електрохімічні; оптичні; на основі оксиду кремнію, кварцу та скла; на основі наноматеріалів; генетично кодовані або синтетичні фрлуоресцентні; мікробні, розроблені за допомогою синтетичної біології та генетичної інженерії. Досліджувані системи порівняно за технологією, специфічністю, порогом виявлення, тривалістю аналізу, вартістю та портативністю.

Розглянуто методи виготовлення електрохімічних кіберфрізичних біосенсорних та імуносенсорних систем. Окремо представлено методи виготовлення, шляхом модифрікування поверхні металевих і вуглецевих електродів із використанням біоматеріалів, таких як ферменти, антитіла або ДНК. Представлено оптичні досліджувані системи, що реалізуть свою дію за допомогою іммобілайзерів і можуть виготовлятися із золота, матеріалів на основі вуглецю, кварцу або скла. Описано найбільш важливі напрями використання кіберсрізичних біосенсорних та імуносенсорних систем у лікувальних і діагностичних закладах, зокрема для моніторингу рівня глюкози в крові пацієнтів із цукровим діабетом, а також для розроблення нових лікарських засобів, біозондування та біомедицини. Зроблено висновок, що досліджувані системи 3 наноматеріалів на основі оксиду кремнію володіють найбільш високим потенціалом щодо застосування для біовізуалізаціі, біосенсорного аналізу та лікування онкологічнх захворювань.

Розглянуто мічені кіберфізичні біосенсорні та імуносенсорні системи з використанням генетичного кодування або синтетичної фрлуоресценції, що дало змогу вивчати біологічні процеси, в тому числі, різні молекулярні перетворення всередині клітин. Наведено переваги візуалізації in vivo за допомогою досліджуваних систем малих молекул з метою кращого розуміння клітинної активності та механізму дії ДНК, РНК та мікро-РНК. Описано клітинні біосенсорні та імуносенсорні системи, що можна застосовувати для моніторингу біохімічної потреби в кисні, токсичності в навколишньому середовищі, для виявлення пестицидів і важких металів, спостереженні за екологічною ефективністю при виробництві електроенергії. Зроблено висновок, що для створення високочутливих мініатюрних пристроїв потрібне розроблення різних мікро- і нано-кіберфізичних біосенсорних та імуносенсорних платорорм із залученням інтегрованих технологій, які використовують електрохімічний або оптичний біоелектронні принципи 3 комбінацією біомолекул або біологічних матеріалів, полімерів і наноматеріалів.
\end{abstract}

Ключові слова: кіберфізична система, біосенсорна система, імуносенсорна система, портативна система

\section{APPLICATION OF CYBERPHYSIC BIOSENSORS AND IMMUNOSENSORS SYSTEMS}

\author{
V. P. Martsenyuk, A. S. Sverstiuk ${ }^{1}$, T. V. Bihunyak ${ }^{1}$, \\ A. V. Pavlyshyn ${ }^{1}$, O. M. Mochulska ${ }^{1}$ \\ University of Bielsko-Biala, the Republic of Poland \\ ${ }^{1}$ SHEE I. Horbachevsky Ternopil State Medical University of the Ministry of Health of Ukraine
}

\begin{abstract}
Background. The artical reviews the cyber-physical biosensor and immunosensory systems, which are the new generation of information-measuring systems with the use in the design of biological materials, which ensures their high selectivity. It is considered the following types of cyberphysical biosensory and immunosensory systems: electrochemical; optical on the basis of silicon oxide, quartz and glass; on the basis of nanomaterials; genetically coded or synthetic fluorescent; microbial, developed using synthetic biology and genetic engineering.

Materials and methods. It is carried out the classification of the studied systems for relatively sensitive elements and the possibility of using different modes of physico-chemical transformation of the measuring quantity.

Methods of manufacturing electrochemical cyberphysical biosensory and immunosensory methods are considered. Separately presented methods of manufacturing, by modifying the surface of metallic and carbon electrodes using biomaterials such as enzymes, antibodies or DNA.
\end{abstract}


Results. In the article, the studied systems are compared in terms of technology, specificity, detection threshold, analysis duration, cost and portability. Optical research systems, which realize their actions with the help of immobilizers and can be made of gold, carbon-based materials, quartz or glass, are presented. The most important directions of use of cyberphysical biosensor and immunosensory systems in clinics and diagnostic institutions are described, in particular, for monitoring of blood glucose levels in patients with diabetes, as well as for the development of new drugs, biopsy and biomedicine. It is labeled cyberphysical biosensor and immunosensory systems using genetic coding or synthetic fluorescence have been considered, which made it possible to study biological processes, including various molecular transformations within cells. The advantages of visualizing in vivo with the help of small molecule systems are described in order to better understand the cellular activity and mechanism of action of DNA, RNA and microRNA. Cellular biosensor and immunosensory systems that can be used to monitor the biochemical oxygen demand, environmental toxicity, to detect pesticides and heavy metals, and to monitor environmental efficiency in electricity generation are described.

Conclusions. The studied systems of silicon-based nanomaterials have the highest potential in terms of application for bivamisalizatsii, biosensor analysis and treatment of oncological diseases. The creation of high sensitive miniature devices requires the development of various micro and nano-cyberphysical biosensor and immunosensory platforms with the use of integrated technologies that use electrochemical or optical bioelectronic principles with a combination of biomolecules or biological materials, polymers and nanomaterials.

Key words: cyberphysical system, biosensor system, immunosensory system, portable system.

\title{
ПРИМЕНЕНИЕ КИБЕРФИЗИЧЕСКИХ БИОСЕНСОРНЫХ И ИММУНОСЕНСОРНЫХ СИСТЕМ
}

\author{
В. П. Марценюк, А. С. Сверстюк ${ }^{1}$, Т. В. Бигуняк ${ }^{1}$, \\ А. В. Павлишин ${ }^{1}$, О. М. Мочульская ${ }^{1}$ \\ Университет Бельско-Бялы, Республика Польша

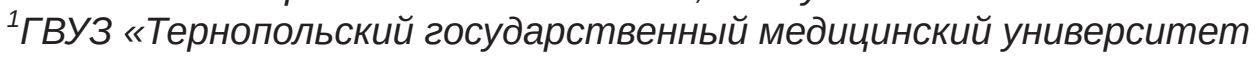 \\ имени И. Я. Горбачевского МЗ Украины»
}

В работе представлен обзор киберсизических биосенсорных и иммуносенсорных систем, являющихся новым поколением информационно-измерительных систем с использованием в конструкции биологических материалов, что обеспечивает их высокую селективность. Проведена классификация исследуемых систем в отношении чувствительных элементов и возможности использования различных режимов фризико-химического преобразования измеряемой величины. Рассмотрены следующие виды киберфизических биосенсорных и иммуносенсорных систем: электрохимические; оптические; на основе оксида кремния, кварца и стекла; на основе наноматериалов; генетически кодированные или синтетические фрлуоресцентные; микробные, разработанные при помощи синтетической биологии и генетической инженерии. Проведено сравнение исследуемых систем по технологии, специфичности, порогу обнаружения, продолжительности анализа, стоимости и портативности. Рассмотрены методы изготовления электрохимических киберфизических биосенсорных и иммуносенсорных систем. Отдельно представлены методы изготовления, путем модисицирования поверхности металлических и углеродных электродов с использованием биоматериалов, таких как ферменты, антитела или ДНК. Представлены оптические исследуемые системы, которые реализуют свое действие при помощи иммобилайзеров и могут изготавливаться из золота, материалов на основе углерода, кварца или стекла. Описаны наиболее важные направления использования киберфизических биосенсорных и иммуносенсорных систем в лечебных и диагностических заведениях, в частности, для мониторинга уровня глюкозы в крови пациентов с сахарным диабетом, а также для разработки новых лекарственных средств, биозондирования и биомедицины. Сделан вывод, что исследуемые системы из наноматериалов на основании оксида кремния обладают наиболее высоким потенциалом по применению для биовизуализации, биосенсорного анализа и лечения онкологических заболеваний. Рассмотрены меченные киберфизичические биосенсорные и иммуносенсорные системы с использованием генетического кодирования или синтетической флуоресценции, что позволило изучать биологические процессы, в том числе, различные молекулярные превращения внутри клеток. Приведены преимущества визуализации in vivo при помощи исследуемых систем малых молекул с целью лучшего понимания клеточной активности и механизма действия ДНК, РНК и микро-РНК. Описаны клеточные биосенсорные и имуносенсорные системы, которые можно применять для мониторинга биохимической потребности в кислороде, токсичности в окружающей среде, для выявления пестицидов и тяжелых металлов, наблюдения за экологической эфффективностью при производстве электроэнергии. Сделан вывод, что для создания высокочувствительных миниатюрных устройств требуется разработка различных микро- и нано-киберфизических биосенсорных и иммуносенсорних платформ с привлечением интегрированных технологий, использующих электрохимический или оптический биоэлектронные принципы с комбинацией биомолекул или биологических материалов, полимеров и наноматериалов.

Ключевые слова: киберфизическая система, биосенсорная система, иммуносенсорная система, портативная система. 
Вступ. В останні роки спостерігаємо стрімкий розвиток науки та техніки, пов'язаний з появою нових методів детекції. Тому в науці, медицині та промисловості зростає інтерес до кіберфізичних систем (КФС), що є фізичними системами з можливістю інтеграції обчислень та фізичних процесів. Функціонування КФС тісно пов'язано з роботизованими та сенсорними системами, що обладнані «розумними» механізмами з достатніми обчислювальними можливостями для ефективного керування.

В останні роки ефективно використовуються кіберфізичні біосенсорні та імуносенсорні системи (КФБСІСС), що є альтернативою відомим методам вимірювання, котрі характеризуються поганою вибірковістю, високою вартістю, поганою стабільністю, повільною реакцією та часто можуть бути виконані тільки висококваліфікованим персоналом. Це нове покоління давачів, які використовують в конструкції біологічний матеріал, що забезпечує дуже високу селективність та дає змогу швидко та просто проводити вимірювання [1].

Мета роботи: представити розроблену класифікацію КФБСІСС на основі чутливих елементів із можливістю застосування в медицині та з використанням різних режимів фізико-хімічного перетворення вимірювальної величини. Навести технічні стратегії, що застосовуються для розроблення біосенсорних та імуносенсорних систем.

\section{Результати та їх обговорення.}

Аналіз останніх досліджень. Для кількісного оцінювання інфікування організму за допомогою певних електрохімічних чи оптичних явищ у КФС використовуються клітинні біосенсори. У роботі [2] описано клітинний біосенсор, в якому використано електрохімічну імпедансну спектроскопію. Цей біосенсор призначений для підрахунку людських клітин CD4+. Ділянка його зондування включає електродні пікселі, кожний з яких дорівнює за розміром клітині CD4+, захопленій пікселями електроду. Ці клітини виявляють шляхом спостереження за інформативними змінами на пікселі. Стан «ввімкнено» або «вимкнено» електродного пікселя вказує на виявлення однієї CD4+ клітини [3]. Отже, щоб підрахувати клітини $\mathrm{CD} 4+$, потрібно підсумувати електродні пікселі в стані «ввімкнено».

Найчастіше КФС розробляються у вигляді вбудованих систем і мереж для моніторингу та контролю фізичних процесів у системах зі зворотнім зв'язком. У таких системах динаміка фізичних процесів є джерелом інформації досліджуваного явища 3 можливістю контролю та розрахунку сигналів керування об'єктом [4]. Кібер-фізичні системи ототожнюють 3 проявом четвертої промислової революції, що відбувається в сучасному світі [5]. Існує також фізична можливість використання технологій «Internet of Things (Інтернет речей)», коли необхідно використовувати сигнали від давачів і вимірювальних приладів.

Тобто, з'являється все більше публікацій, що привертають увагу до сучасних концепцій і пропонують нові інноваційні рішення. Наприклад, у роботі [6] А. Платцер запропонував підхід на основі «динамічної логіки», де описано та проаналізовано КФС.

КФБСІСС є високоінтелектуалізованими інформаційними системами. Вони використовують доступний набір інтерфейсів, що дають змогу отримувати швидку та достовірну інформацію про стан і внутрішні дані системи, доступні для інших КФС. Відповідно до [7] КФБСІСС як самоорганізуюча система потребує всебічних знань про власну динамічну структуру та інфраструктуру загальної системи. Для цього необхідно визначити типи імуносенсорних пристроїв, враховуючи їх функціональне застосування. Наприклад, імуносенсори можна використовувати для оцінки критичних станів при серцево-судинних захворюваннях, об'єму інсуліну при вимірюванні вмісту глюкози в крові та виявлення кількісних показників у деяких фармацевтичих сполуках $[7,8]$.

Підходи до розробки КФБСІСС. У роботах $[9,10]$ розроблено та досліджено математичні моделі КФБСІСС. У роботі [11], при розробці КФБСІСС, представлено використання технічних підходів, що засновані на виявленні біомаркерів $з$ використанням і без використання міток. Детектування з використанням міток засноване переважно на специфічних властивостях мічених з'єднань, що застосовуються для прицільного виявлення. КФБСІСС такого типу надійні, проте часто вимагають комбінації специфічних чутливих елементів, що виготовляються з використанням іммобілізованого білка-мішені. 3 іншого боку, методи $[12,13]$, що не використовують міток дають змогу виявляти молекули-мішені, не придатні для маркування. Останні міждисциплінарні підходи в галузі біотехнології та біоінженерії, електротехніки та електроніки зумовили розробку КФБСІСС, що не використовують маркери для різних методів виявлення 3 широким спектром напрямів застосування в галузі медицини, моніторингу якості 
продуктів харчування, оборонної промисловості та охорони навколишнього середовища. До основних технічних характеристик КФБСІСС відповідно до [14] належать селективність, чутливість, точність, відтворюваність, час відгуку, час регенерації та термін експлуатації.

Розглянемо такі види КФБСІСС: електрохімічні; оптичні; на основі оксиду кремнію, кварцу і скла; на основі наноматеріалів; генетично кодовані або синтетичні флуоресцентні; мікробні КФБСІСС, розроблені за допомогою синтетичної біології та генетичної інженерії [15].

Електрохімічні КФБСІСС. Створення глюкометра на основі глюкозооксидазного біосенсора [16] $\epsilon$ першим кроком в історії розроблення електрохімічних КФБСІСС. Такі системи дуже популярні в лікувальних і діагностичних закладах, оскільки необхідні для періодичного моніторингу рівня глюкози в крові пацієнтів із цукровим діабетом. Проте ці КФБСІСС мають недоліки в силу нестабільної активності або негомогенності ферменту [17], що зумовлює важливість додаткового калібрування. Фактично ці потенційні недоліки привели до розробки спектру біомолекул [11], які володіють різними електрохімічними властивостями, що зумовило появу більш стабільно працюючих КФБСІСС глюкози. Останнім часом електрохімічні КФБСІСС, як правило, виготовляються шляхом модифікування поверхні металевих і вуглецевих електродів із використанням біоматеріалів, таких як ферменти, антитіла або ДНК. Вихідний сигнал КФБСІСС зазвичай генерується в результаті специфічних реакцій зв'язування або каталітичних реакцій між матеріалами [18] на поверхні електроду. Необхідність розроблення електрохімічних КФБСІСС стала особливо актуальна для клінічної діагностики захворювань [7-9, 19], в яких велике значення має раннє виявлення або довготривалий моніторинг біологічних показників. У даному контексті для розробки неферментативних КФБСІСС замість білків використовуються синтетичні матеріали. Різні типи біомолекул володіють різною стабільністю та вибірковістю, що в кінцевому підсумку дає змогу розробляти нові типи електрохімічних КФБСІСС для різної мети. Залежно від галузі застосування були розроблені різні типи електрохімічних КФБСІСС.

Оптичні КФБСІСС. Відомо, що біомедицина та екологія вимагають розробки простих, швидко працюючих і високочутливих КФБСІСС. Це може бути реалізовано за допомогою іммобілайзерів
[11, 20-25], що можуть виготовлятися із золота, матеріалів на основі вуглецю, кварцу або скла. Використання золотих наночастинок або квантових точок з використанням мікротехнологічних методів являє собою нову технологію розробки високочутливих і портативних КФБСІСС на основі ферменту цитохрому P450 для застосування в певних цілях. Більш того, оптоволоконні хімічні сенсори дуже актуальні для різних галузей, таких як пошук нових лікарських засобів, біозондування та біомедицини. Останнім часом гідрогелі, що застосовують в якості сенсорів на основі ДНК (дезоксирибонуклеїнова кислота), набувають популярності в якості матеріалів для іммобілізації в оптоволоконній хімії [25]. У порівнянні з іншими матеріалами іммобілізація в гідрогелі відбувається у трьох вимірах, що забезпечує завантаження великої кількості чутливих молекул. Гідрогелі (поліакриламід) представляють собою гідрофільні полімери [26] з поперечними зв'язками, яким для іммобілізації можна надавати різні форми, починаючи від тонких плівок і закінчуючи наночастинками. Гідрогелі вважаються простим субстратом для іммобілізації ДНК, що мають низку переваг, таких як можливість утримання молекул, їх контрольованого вивільнення, збагачення аналітів і захисту ДНК. Ці характеристики унікальні для гідрогелів у порівнянні з іншими матеріалами, придатними для біомолекулярної іммобілізації [26]. Більше того, гарна оптична прозорість гідрогелів надає можливість застосування зручної стратегії візуального виявлення. Методи іммобілізації ДНККФБСІСС [26] у монолітних поліакриламідних гелях і гелевих мікрочастинках часто розглядаються як технічне досягнення в області кіберфізичних технологій. Виявлення одиничних молекул для ідентифікації ДНК також стало можливим за допомогою електрохімічного окислення гідрозину [27].

КФБСІСС на основі оксиду кремнію, кварцу та скла. Пошук нових методів розробки КФБСІСС привів до використання унікальних властивостів матеріалів з оксиду кремнію, кварцу та скла. Серед цих матеріалів особливе місце займають наноматеріали на основі оксиду кремнію, що володіють найбільш високим потенціалом для використання у виробництві КФБСІСС завдяки своїй біосумісності, доступності, а також електронним, оптичним та механічним властивостям. Більш того, такі матеріали нетоксичні, що є дуже важливою умовою для біомедичних і біологічних сфер застосування. Матеріали на основі оксиду кремнію 
[22, 23] можуть використовуватися для біовізуалізаціі, біосенсорного аналізу та для лікування онкологічнх захворювань. Цікавим є той факт, що нанопроводи з оксиду кремнію в комбінації з золотими наночастинками є гідридні структури [23], що застосовуються в рамках революційних підходів до лікування онкологічнх захворювань. Ковалентне прикріплення модифікованих тіолами олігомерів ДНК до оксиду кремнію або скла забезпечує формування ДНК-плівок, що підвищують ефективність УФ-спектроскопії та методів гібридизації [26]. Незважаючи на безліч переваг застосування наночасток з оксиду кремнію, існує цілий ряд труднощів, що потребують вирішення. Серед них слід відзначити розробку методів великомасштабного малозатратного виробництва, а також біосумістності після біомолекулярного контакту. Вирішення цих питань забезпечить можливість перетворення наноматеріалів на основі оксиду кремнію в компоненти сучасних КФБСІСС.

Унікальні характеристики матеріалів на основі оксиду кремнію, кварцу або скла дали змогу розробити кілька нових високотехнологічних КФБСІСС для вдосконалення вимірювальних приладів, що застосовуються в області біомедичних технологій [11, 21-23].

КФБСІСС на основі наноматеріалів. Для іммобілізації КФБСІСС використовується широкий спектр наноматеріалів, у тому числі наночастинки золота, срібла, оксиду кремнію та міді, а також матеріали на основі вуглецю, такі як графіт, графен і вуглецеві нанотрубки [13, 20, 28, 29, 30-33]. При розробці електрохімічних та інших КФБСІСС матеріалів на основі наночастинок забезпечується висока чутливість та специфічність. Серед металевих наночастинок для практичного використання найбільш придатні золоті наночастинки, стійкі до окислення [34] та практично нетоксичні. У той же час наночастинки з інших металів, таких як срібло, при введенні в організм, наприклад, для доставки препаратів, окислюються та надають токсичну дію. В цілому застосування наноматеріалів у біомедичних КФБСІСС асоційоване з потенційними складнощами [35]. Більш того, підходи до підсилення сигналу за допомогою наночастинок мають потенційні переваги та недоліки [36]. Проте, наноматеріали вважаються важливими компонентами КФБСІСС, завдяки їх здатності підвищувати чутливість і пороги виявлення при детектуванні одиничних молекул [11]. В якості прикладу можна навести використання наночастинок на основі платини для електрохімічної ампліфікації з однорівневою реакцією для виявлення низької концентрації ДНК [27]. Аналогічним чином напівпровідникові квантові точки та нанокристали з оксиду заліза, що володіють як оптичними, так і магнітними властивостями, можна ефективно пов’язувати з пухлиноспецифічними лігандами, такими як моноклональні антитіла, пептиди або малі молекули, для прицільного впливу на пухлинні антигени з високою афінністю та специфічністю [37]. Технологія квантових точок може застосовуватися при вивченні пухлинного мікрооточення при проведенні терапії, а також для транспортування нанопрепаратів.

Генетично кодовані або синтетичні флуоресцентні КФБСІСС. Розробка мічених КФБСІСС із використанням генетичного кодування чи синтетичної флуоресценції надала можливість вивчати біологічні процеси, в тому числі різні молекулярні шляхи всередині клітин [39-41]. Фактично метод виявлення мічених флуоресценцією антитіл вперше був розроблений для отримання зображень фіксованих клітин [40]. Ця стратегія надала нові можливості розробки таких КФБСІСС з використанням біологічних білків і малих молекул, що зв’язуються з аналітичними та вторинними месенджерами. Згодом були розроблені флуоресцентні КФБСІСС для аналізу рухових білків, що використовують метод виявлення поодиноких молекул при певній концентрації аналіту [39]. Незважаючи на ці переваги, методологія виявлення та аналізу міткок виглядає складною. Винахід зеленого флуоресцентного білка та інших флуоресціюючих білків надало ряд переваг з точки зору дизайну та ефективності оптичного зонду [40]. За останнє десятиліття генетично закодовані КФБСІСС, специфічні до молекул, що залучені в синтез енергії активних форм кисню та АТФ (аденозинтрифосфат) дали змогу краще вивчити фізіологію мітохондрій. АТФ $\epsilon$ важливою сигнальною молекулою та терапевтичної мішенню для серцево-судинної системи. 3 огляду на це КФБСІСС, що функціонують на основі методу резонансного переносу енергії флуоресценції, були розроблені для візуалізації АТФ та іонів кальцію всередині клітини. Деякі з таких КФБСІСС ефективно застосовуються для in vivo візуалізації в первинних культурах і живих клітинах [40, 41]. На сьогоднішній день опрацьовано досить багато аспектів розробки КФБСІСС для візуалізації в умовах живого організму. 3'явилися в результаті оптимізації таких підходів малокутове розсіювання рентгенівських променів для розробки кальцієвих каналів і резонансний перенос енергї флуоресценції 
визнані найкращими КФБСІСС методиками в сучасній фізіології [40]. Як пояснювалося раніше, електрохімічні, електромеханічні і оптичні КФБСІСС розробляються для більш ефективного, в порівнянні з іншими молекулярними методиками, виявлення мікроРНК. Отже, був розроблений ряд специфічних до певних мішеней КФБСІСС на основі мікроорганізмів (бактерій) і клітинних органел [42, 44].

Завдяки появі in vivo візуалізації за допомогою КФБСІСС малих молекул з'явилася можливість краще зрозуміти клітинну активність та механізми дії багатьох інших молекул, у тому числі ДНК, РНК та мікроРНК. Перспективним напрямком $\epsilon$ використання оптичних КФБСІСС. Вважається, що на сучасному етапі оптичні КФБСІСС при поєднанні технології флуоресценції та використання наноматеріалів, дають змогу отримувати кращі результати з точки зору застосування та чутливості.

Клітинні КФБСІСС. Протягом останніх років для моніторингу стану навколишнього середовища та біологічної очистки застосовуються останні інноваційні технології, що засновані на генетичній інженерії та синтетичній біології. Такі підходи використовуються для програмування мікроорганізмів, наділяючи їх специфічними вихідними сигналами, чутливістю та селективністю. Наприклад, живі клітини, що володіють ферментативною активністю, котра забезпечує деградацію ксенобіотичних з'єднань, будуть мати широке застосування для біологічної очистки [45]. Також були розроблені КФБСІСС на мікробному паливі для моніторингу біохімічної потреби в кисні та токсичності в навколишньому середовищі. Бактерії мають властивість деградувати органічний субстрат і генерувати електричний сигнал для ферментації. По суті технологія полягає у використанні біоелектрохімічних пристроїв, що регулюють силу мікробного дихання для конвертації органічних субстратів безпосередньо в електричну енергію. Незважаючи на ці можливості, обмеження застосування мікробних КФБСІСС обумовлені низькою питомою потужністю з точки зору собівартості та експлуатаційних витрат. Завдяки останнім розробкам вдалося значно поліпшити продуктивність і знизити витрати за допомогою нових системних підходів, що дозволило створити на основі цих технологій платформу, яка володіє заданими властивостями клітинних КФБСІСС з автономними джерелами живлення [46, 47]. Ще однією областю використання клітинних КФБСІСС $є$ їх застосування для виявлення пестицидів і важких металів [48], при якому еукаріотичні мікроорганізми мають перевагу перед прокаріотами. Це переважно зумовлено перевагою розробки цілоклітинних КФБСІСС [48] для виявлення токсичності пестицидів і важких металів з високою вибірковістю та чутливістю. Крім цього, більш складні еукаріотичні мікроорганізми можуть володіти більш широким спектром чутливості до різних токсичних молекул і мають кращу спорідненість до тварин. Мікробні КФБСІСС мають широкий спектр застосування, починаючи від моніторингу навколишнього середовища і закінчуючи виробництвом енергії. У майбутньому такі клітинні КФБСІСС $[46,47]$ матимуть більш широке застосування для моніторингу забруднення навколишнього середовища важкими металами та екологічної еффективності при виробництві електроенергії.

Порівняльний аналіз КФБСІСС. Проведемо порівняння КФБСІСС з точки зору технології, специфічності та порогу виявлення, діапазону лінійності, тривалості аналізу, вартості та портативності.

Інновації в області електрохімічних сенсорів з високою пропускною здатністю, спрямовані на оптимізацію порогу виявлення, тривалості аналізу та портативності, забезпечили появу масштабних споживчих ринків недорогих КФБСІСС, що застосовуються в якості тестів на рівень глюкози та вагітність. Останній заснований на використанні тест-смужок з мобілізованими антитілами до хоріонічного гонадотропіну людини, що виявляються за допомогою технології імунохроматографії [11]. Іммобілізація аналітів за допомогою полімерів i наноматеріалів $є$ ключем до покращення чутливості та порогу виявлення. 3 цієї точки зору, імунохроматографічний аналіз на тест-смужках дозволяє поміщати зразки в задане місце для запуску специфічних взаємодій, а не взаємодій, що відбуваються випадковим чином. Велика частина згаданих вище КФБСІСС заснована на цій технології, ящо фактично проклала шлях біовиробництва з використанням контактного та безконтактного формування. Використання для біовиробництва наноматеріалів, таких як золото, срібло та оксид кремнію, призвело до появи нових методів. Крім цього нанесення полімерного покриття на такі наноматеріали зробило суттєвий розвиток у сфері контактних електрохімічних методів реєстрації сигналів. Одним з основних переваг цього типу електрохімічних сенсорів $€$ 
чутливість і специфічність при проведенні аналізу в режимі реального часу. Обмеженнями в даному випадку є здатність до регенерації або довготривале використання полімерів або інших матеріалів, однак зниження вартості робить такі електрохімічні КФБСІСС більш доступними. Виявлення одного аналіту за допомогою методів контактної реєстрації сигналу має величезні переваги, наприклад, можливість зміни концентрації молекул з високою специфічністю в режимі реального часу. Для покращення специфічності та чутливості при виявленні поодиноких молекул були впроваджені такі технології, як резонансне перенесення енергії флуоресценції та біолюмінісценціі, а також перетворювачів на основі флуоресценції і плазменного резонансу [25]. При одночасному виявленні декількох аналітів ці технології мають обмеження, обумовлені накладанням емісії сигналів, однак методи, засновані на резонансному перенесення енергії, часто застосовують в таких ситуаціях, що має дуже велике значення для клінічної діагностики через відмінності рівнів біомаркерів у різних пацієнтів і при схожих патологіях. Застосування нано-технологій при біовиробництві перетворювачів для електрохімічних КФБСІСС дає змогу одночасного виявляти декілька аналітів. Також хороші результати продемонстрували безконтактні КФБСІСС, виготовлені за методом трьохвимірного біодруку за допомогою струменевих або лазерних принтерів. Однак, слід зазначити, що останні методи є досить дороговартністними, що накладає на них серйозні обмеження. Цікавим є факт, що більшість з КФБСІСС мають високу пропускну здатність для виконання специфічних цілей, що зумовило використовувати в них методи електрохімічної реєстрації. Деякі з найбільш гідних уваги портативних амперометричних електрохімічних КФБСІСС, що працюють у режимі реального часу, були розроблені для діагностики захворювань з використанням біологічних рідин. У цілому електрохімічні КФБСІСС у комбінації біовиробництва мають низький поріг виявлення для індивідуальних аналітів при проведенні аналізу в режимі реального часу, а також доступну ціну, враховуючи портативність пристрою.

Оптичні КФБСІСС є ще однією важливою технологією в галузі біосенсорного аналізу, що грунтується на застосуванні оптоволоконної хімії. Виявлення індивідуальних молекул, наприклад, ДНК або пептидів, найбільш ефективно при використанні перехресно-зшитих гідрогелів, що мають високий коефіцієнт місткості та гідрофільну природу. Розроблено оптичні КФБСІСС для вимірювання кількості ДНК [27], що мають широке застосування в біомедицині та криміналістиці. Комбінації біологічних матеріалів, такі як ферменти, субстрати, антитіла, антигени та нуклеїнові кислоти зробили революцію в технологї оптичних КФБСІСС. Крім цього в КФБСІСС можна інкорпорувати мікроорганізми, тваринні або рослинні клітини, а також зрізи тканин. Останні досягнення в галузі молекулярної оптоелектроніки зумовили можливість появи оптичних біометричних систем розпізнавання. Інтегровані оптичні технології дають змогу інкорпорувати як пасивні, так і активні оптичні компоненти у той самий субстрат для розробки мінімізованих компактних реєструючих пристроїв при виробництві багатьох сенсорів на одному чіпі. В даному контексті високоякісні полімери використовуються для виготовлення гібридних систем для оптичних КФБСІСС. Технологія даних систем була вдосконалена за допомогою сучасних інновацій в області аналізу морфології поверхонь за допомогою високотехнологічної електронної мікроскопії. Сучасні оптичні технології з використанням наномеханічних КФБСІСС на основі технології поверхневого резонансу покладені в основу інноваційних ДНК-чипів для проведення специфічного та чутливого аналізу в режимі реального часу [49-50]. Переваги оптичних КФБСІСС головним чином полягають у високій швидкості проведення аналізу з можливістю забезпечення стійкості сигналу під час вимірювання. Основним недоліком при цьому $\epsilon$ висока вартість, що обумовлена певними вимогами до устаткування. Вирішення технічних проблем, таких як складність іммобілізації, особливо для біовиробництва, та необхідність стерильних умов, є критичним питанням для отримання максимальної користі від оптичних КФБСІСС.

Біовиробництво медичних систем забезпечує кращі результати з точки зору масового виробництва КФБСІСС. Електрохімічні та оптичні КФБСІСС є основними технологічними компонентами при розробці високоякісних систем. Серйозні досягнення в області технологій мікро- та нановиробництва забезпечили можливість розробки механічних пристроїв 3 рухомими деталями нанорозмірів. Можливість виробництва таких структур із застосуванням процедур обробки напівпровідникових матеріалів об’єднали біофізичні та біоінженерні принципи в напряму прогресу мікро- та наноелектромеханічних КФБСІСС, придатних для масового виробництва. Матеріали на основі скла, оксиду кремнію та кварцу успішно використовуються 
після мічення флуоресціюючими агентами або золотими наночастинками. Незважаючи на те, що такі КФБСІСС володіють більш високою точністю при виявленні індивідуальних молекул, однак Ïх масове виробництво не $є$ дешевим [22, 23]. Масове виробництво КФБСІСС пов’язано з певними проблемами, а саме із складністю міцнішого зв’язування агентів на нанорівнях при виробництві за допомогою мікроелектронних технологій для високошвидкісного аналізу. В цьому відношенні варто згадати величезний потенціал застосування напівпровідникових матеріалів і технології квантових точок. На сьогодні жодна з існуючих КФБСІСС технологій не дає змогу в режимі реального часу здійснювати одночасний кількісний аналіз великих масивів зразків, однак ефективне впровадження нанотехнологій може зробити це реальністю [25].

Ще одним важливим технічним досягненням у галузі розробки біосенсорних та імуносенсорних систем стала можливість створення генетично закодованих або синтетичних флуоресцентних КФБСІСС для аналізу молекулярних механізмів біологічних процесів [39-41]. Незважаючи на те, що такі КФБСІСС мають величезні перспективи в області виявлення окремих молекул з вимірюванням кількості специфічного аналіту, методологія попередньої підготовки та виявлення дуже складна та вимагає високотехнологічного обладнання. 3 точки зору біоматеріалів, хорошими характеристиками в плані високої чутливості та вибірковості мають КФБСІСС, що працюють на мікробіологічних паливних елементах. Однак методи масової продукції і генної інженерії, що вимагаються для створення штаму мікроорганізмів, дуже складні та не $є$ дешевими. В той же час, перевагою мікробних КФБСІСС є можливість їх використання в якості інструменту для біоремедіації, що має велике значення з точки зору моніторингу стану навколишнього середовища. Однак розробка та вивільнення в навколишнє середовище такого генетично модифікованого штаму мікроорганізмів, крім регулювання витрат на виробництво, має піддаватися суворому контролю, відповідати етичним вимогам, а також регулюватися законодавством.

Інтегровані стратегії з використанням сучасних технологій розробки КФБСІСС [15], починаючи від електрохімічних, електромеханічних, флюоресцентної-оптичних і закінчуючи генетично модифікованими мікроорганізмами, є сучасними методами розробки досліджуваних систем (табл. 1) та їх застосування для діагностики захворювань (табл. 2).

Таблиця 1

Класифікація КФБСІСС відносно принципів їх роботи та галузей застосування

\begin{tabular}{|c|c|c|c|}
\hline $\begin{array}{l}\text { № } \\
\text { 3/П }\end{array}$ & $\begin{array}{c}\text { Назва } \\
\text { КФБСІСС }\end{array}$ & $\begin{array}{c}\text { Фізико-хімічні методи, що } \\
\text { лежать в основі вимірювання }\end{array}$ & $\begin{array}{c}\text { Галузі застосування } \\
\text { КФБСІСС }\end{array}$ \\
\hline 1. & $\begin{array}{l}\text { КФБСІСС на основі елек- } \\
\text { тродів з іммобілізован- } \\
\text { ною глюкозооксидазою }\end{array}$ & $\begin{array}{l}\text { Електрохічні методи з ви- } \\
\text { користанням окислення } \\
\text { глюкози }\end{array}$ & $\begin{array}{l}\text { Аналіз рівня глюкози в біологічних } \\
\text { зразках }\end{array}$ \\
\hline 2. & $\begin{array}{l}\text { КФБСІСС для вимірю- } \\
\text { вання рівня гемоглобіну }\end{array}$ & $\begin{array}{l}\text { Електрохічні методи з вико- } \\
\text { ристанням ферроценілборної } \\
\text { кислоти }\end{array}$ & $\begin{array}{l}\text { Надійний аналітичний метод для аналізу } \\
\text { гемоглобіну }\end{array}$ \\
\hline 3. & $\begin{array}{l}\text { КФБСІСС для вимі- } \\
\text { рювання рівня сечової } \\
\text { кислоти }\end{array}$ & Електрохічні методи & $\begin{array}{l}\text { Для виявлення клінічний аномалій або } \\
\text { захворювань }\end{array}$ \\
\hline 4. & $\begin{array}{l}\text { КФБСІСС на основі } \\
\text { інгібування ацетилхолі- } \\
\text { нестерази }\end{array}$ & Електрохічні методи & Аналіз впливу пестицидів \\
\hline 5. & $\begin{array}{l}\text { П’єзоелектронні } \\
\text { КФБСІСС }\end{array}$ & Електрохічні методи & Виявлення органофосфатів і карбаматів \\
\hline 6. & $\begin{array}{l}\text { Мікротехнологічні } \\
\text { КФБСІСС }\end{array}$ & $\begin{array}{l}\text { Оптичні методи з використан- } \\
\text { ням ферменту цитохрому P450 }\end{array}$ & Для розробки лікарських засобів \\
\hline 7. & $\begin{array}{l}\text { КФБСІСС на основі гід- } \\
\text { рогелю (поліакриламіду) }\end{array}$ & Оптичні методи & Для іммобілізації біомолекул \\
\hline
\end{tabular}




\begin{tabular}{|c|c|c|c|}
\hline $\begin{array}{l}\text { № } \\
\text { З/П }\end{array}$ & $\begin{array}{c}\text { Назва } \\
\text { КФБСІСС }\end{array}$ & $\begin{array}{c}\text { Фізико-хімічні методи, що } \\
\text { лежать в основі вимірювання }\end{array}$ & $\begin{array}{c}\text { Галузі застосування } \\
\text { КФБСІСС }\end{array}$ \\
\hline 8. & $\begin{array}{l}\text { КФБСІСС на основі } \\
\text { оксиду кремнію }\end{array}$ & $\begin{array}{l}\text { Оптично-флуоресцентні } \\
\text { методи }\end{array}$ & $\begin{array}{l}\text { Біовізуалізація, біосенсорне виявлення і } \\
\text { терапія онкологічних захворювань }\end{array}$ \\
\hline 9. & $\begin{array}{l}\text { КФБСІСС на кристалах } \\
\text { кварцу }\end{array}$ & Електромагнітні методи & $\begin{array}{l}\text { Для розробки ультрависокочутливих } \\
\text { методів виявлення білків у рідинах }\end{array}$ \\
\hline 10. & $\begin{array}{l}\text { КФБСІСС на основі на- } \\
\text { номатеріалів }\end{array}$ & $\begin{array}{l}\text { Електрохімічні або оптично- } \\
\text { флуоресцентні методи }\end{array}$ & $\begin{array}{l}\text { Для біомедицини в якості інструментів } \\
\text { для діагностики }\end{array}$ \\
\hline 11. & $\begin{array}{l}\text { Генетично закодовані або } \\
\text { мічені флуоресцентним } \\
\text { агентом КФБСІСС }\end{array}$ & Флуоресцентні методи & $\begin{array}{l}\text { Для вивчення біологічних процесів, у } \\
\text { тому числі різних внутрішньоклітинних } \\
\text { молекулярних систем }\end{array}$ \\
\hline 12. & $\begin{array}{l}\text { КФБСІСС на основі мі- } \\
\text { кробіологічних елементів }\end{array}$ & Оптичні методи & $\begin{array}{l}\text { Для моніторингу біохімічної потреби в } \\
\text { кисні та токсичності в навколишньому } \\
\text { середовищі (важкі метали та пестициди) }\end{array}$ \\
\hline
\end{tabular}

У табл. 2 наведено основні КФБСІСС для діагностики захворювань та застосування в медицині.

Таблиця 2

\section{Застосування КФБСІСС для діагностики захворювань}

\begin{tabular}{|c|c|c|}
\hline $\begin{array}{l}\text { № } \\
\text { 3/П }\end{array}$ & $\begin{array}{c}\text { Назва } \\
\text { КФБСІСС }\end{array}$ & $\begin{array}{c}\text { Діагностика захворювань або застосування } \\
\text { в медицині КФБСІСС }\end{array}$ \\
\hline 1 & $\begin{array}{l}\text { КФБСІСС на основі електродів з іммобіолізова- } \\
\text { ною глюкозооксидазою }\end{array}$ & Цукровий діабет \\
\hline 2 & КФБСІСС для контролю сечової кислоти & $\begin{array}{l}\text { Діагностика серцево-судинних захворювань і за- } \\
\text { хворювань загального профілю }\end{array}$ \\
\hline 3 & Мікротехнологічні КФБСІСС & Корекція зору \\
\hline 4 & КФБСІСС на основі гідрогелю (поліакриламіду) & Регенеративна медицина \\
\hline 5 & КФБСІСС на основі оксиду кремнію & $\begin{array}{l}\text { Розробка та застосування маркерів онкологічних } \\
\text { захворювань }\end{array}$ \\
\hline 6 & КФБСІСС на основі наноматеріалів & Для терапевтичного застосування \\
\hline
\end{tabular}

Для діагностики в домашніх умовах, проведення скринінгових досліджень та експрес-діагностики з використанням телемедичних технологій необхідно використовувати портативні КФБСІСС.

При створенні КФБСІСС для діагностики в домашніх умовах потрібно враховувати такі вимоги:

1) мала тривалість аналізу; 2) невеликі розміри КФБСІСС; 3) простота у використанні;
4) дешевизна як самої КФБСІСС, так і їі чутливого елемента; 5) аналітичні характеристики, що забезпечують отримання достовірних результатів.

У табл. 3 наведено основні типи КФБСІСС, галузі їх застосування, характеристики, а також можливість портативності. 
Типи КФБСІСС, області їх застосування та характеристики

\begin{tabular}{|c|c|c|c|c|}
\hline \multirow{2}{*}{$\begin{array}{l}\text { № } \\
\text { 3/ח }\end{array}$} & \multirow{2}{*}{$\begin{array}{c}\text { Назва } \\
\text { КФБСІСС }\end{array}$} & \multirow{2}{*}{$\begin{array}{c}\text { Області застосування } \\
\text { КФБСІСС }\end{array}$} & \multicolumn{2}{|c|}{$\begin{array}{l}\text { Характеристики } \\
\text { КФБСІСС }\end{array}$} \\
\hline & & & $\begin{array}{c}\text { Типи аналітів, що } \\
\text { можна виявляти }\end{array}$ & $\begin{array}{c}\text { Можливість } \\
\text { портативності }\end{array}$ \\
\hline 1. & $\begin{array}{l}\text { Електрохімічна } \\
\text { КФБСІСС із засто- } \\
\text { суванням мікротех- } \\
\text { нології }\end{array}$ & $\begin{array}{l}\text { Діагностика захворювань та } \\
\text { моніторинг стану навколишнього } \\
\text { середовища }\end{array}$ & $\begin{array}{l}\text { Одиничні та мно- } \\
\text { жинні }\end{array}$ & + \\
\hline 2. & \begin{tabular}{|l} 
Оптична флуорес- \\
центна КФБСІСС
\end{tabular} & $\begin{array}{l}\text { Розробка лікарських препаратів, } \\
\text { біовізуалізація і біосенсорні до- } \\
\text { слідження }\end{array}$ & Одиничні & - \\
\hline 3. & $\begin{array}{l}\text { Оптичний флуорес- } \\
\text { центна КФБСІСС } \\
\text { з використанням } \\
\text { біовиробництва }\end{array}$ & $\begin{array}{l}\text { Розробка лікарських засобів, біо- } \\
\text { візуалізація і біосенсорні дослі- } \\
\text { дження }\end{array}$ & Множинні & - \\
\hline 4. & $\begin{array}{l}\text { Клітинна } \\
\text { КФБСІСС }\end{array}$ & $\begin{array}{l}\text { Виробництво енергії і вивчення } \\
\text { стану навколишнього середовища }\end{array}$ & Одиничні & + \\
\hline 5. & $\begin{array}{l}\text { Електромагнітна } \\
\text { КФБСІСС }\end{array}$ & Біологія білків & Одиничні & - \\
\hline
\end{tabular}

Аналізуючи інформацію, наведену в табл. 1, 3 можна стверджувати, що для створення високочутливих мініатюрних пристроїв потрібна розробка різних мікро- та нано-КФБСІСС платформ із залученням інтегрованих технологій, які використовують електрохімічний або оптичний біоелектронні принципи з комбінацією біомолекул або біологічних матеріалів, полімерів і наноматеріалів.

Висновки. Розробка КФБСІСС переважно спрямована на забезпечення чутливості, специфічності, відсутність токсичності, можливості виявлення малих молекул і економічної ефективності. Ці характеристики в кінцевому підсумку дозволять досягти необхідних критичних параметрів і усунути основні обмеження КФБСІСС технологій. Деякі досягнення, як це видно по комбінуванню електрохімічних підходів із наноматеріалів, призводять до появи нових типів КФБСІСС. 3 цієї точки зору слід зазначити винахід, що полягає в нанесенні на поверхню шкіри у вигляді тимчасового шару електрохімічних біосенсорів для визначення вмісту в організмі хімічних сполук.

У цілому більш ефективне розроблення кіберфізичних систем із поєднанням біовиробництва та методів синтетичної біології, що засновані на застосуванні електрохімічних, оптичних, біоелектронних принципів або їх комбінації, є запорукою успішної розробки потужних КФБСІСС для сучасного життя. 


\section{Література.}

1. Mehrotra P. Biosensors and their applications - a review // Journal of Oral Biology and Craniofacial Research. - 2016. - Vol. 6, no. 2. - P. 153-159.

2. Jiang X., Spencer M. G. Electrochemical impedance biosensor with electrode pixels for precise counting of CD4+ cells: A microchip for quantitative diagnosis of HIV infec- tion status of AIDS patients // Biosensors and Bioelectronics. - 2010. - Vol. 25, no. 7. P. 1622-1628.

3. Luppa P. B., Sokoll L. J., Chan D. W. Immunosensors principles and applications to clinical chemistry // Clinica Chimica Acta. - 2001. - Vol. 314, no. 1. - P. 1-26.

4. Lee E. A. Cyber physical systems: Design challenges. - Center for Hybrid and Embedded Software Systems: EECS University of California, Berkeley, CA 94720, USA, Tech. Rep. UCB/EECS-2008-8, Jan. 2008. Available at: https://www2.eecs.berkeley.edu/Pubs/ TechRpts/2008/ EECS-2008-8.pdf.

5. Lee J., Bagheri B., Kao H.-A. A cyber-physical systems architecture for industry 4.0-based manufacturing system // Manufacturing Letters. - 2015. - Vol. 3. P. 18-23.

6. Berger C., Hees A., Braunreuther S., and Reinhart G. Characterization of cyber-physical sensor system // Procedia CIRP. - 2016. - Vol. 41. - P. 638-643.

7. Martsenyuk V. P., Klos-Witkowska A., Sverstiuk A. S. Study of classification of immunosensors from viewpoint of medical tasks // Medical informatics and engineering. - 2018. - № 1 (41). - P. 13-19.

8. Martsenyuk V. P., Klos-Witkowska A., Sverstiuk A. S., Bihunyak T. V. On principles, methods and areas of medical and biological application of optical immunosensors // Medical informatics and engineering. - 2018. - № 2 (42). - P. 28-36.

9. Martsenyuk V. Stability, bifurcation and transition to chaos in a model of immunosensor based on lattice differential equations with delay / V. Martsenyuk, A. Kłos-Witkowska, A. Sverstiuk // Electronic Journal of Qualitative Theory of Differential Equations. - 2018. No. 27. - P. 1-31.

10. Martsenyuk V. On modelling predator-prey cellular automaton with help of lattice differential equations with time dilay / V. Martsenyuk, A. Klos-Witkowska, A. Sverstiuk, O. Bagrii-Zayats, M. Bernas // Advances in biotechnology. 18th International Multidisciplinary Scientific GeoConference SGEM 2018. Nano, bio, green and space technologies for a sustainable, 2th8th of July, Albena, Bulgaria. - V.18. - ISSUE 6.2. P. 407-414.

11. Byely`x I. A., Kleshhev M. F. Biologichni ta ximichni sensorni sy`stemy`: Navchal`ny`j posibny`k. - Xarkiv: NTU «XPI», 2011. - $143 \mathrm{~s}$.

11. Turner, A. P. Biosensors: sense and sensibility // Chem. Soc. - 2013. - Rev. 42. - P. 3184-3196.

12. Citartan, M., Gopinath, S. C., Tominaga, J., and Tang, T. H. Label-free methods of reporting biomolecular interactions by optical biosensors // Analyst. - 2013. No. 138. - P. 3576-3592.

13. Sang, S., Wang, Y., Feng, Q., Wei, Y., Ji, J., and Zhang, W. Progress of new label-free techniques for biosensors: a review // Crit. Rev. Biotechnol. - 2015. - No. 15. P. 1-17.

15. Vigneshvar S., Sudhakumari C. C., Senthilkumaran Balasubramanian, Prakash Hridayesh Recent Advances in Biosensor Technology for Potential Applications. - An Overview Frontiers in Bioengineering and Biotechnology. - 2016. - Vol. 4. - P. 11.

16. Clark, L. C. Jr., and Lyons, C. Electrode systems for continuous monitoring in cardiovascular surgery // Ann. N. Y. Acad. Sci. - 1962. - No. 102. - P. 29-45.

17. Harris, J. M., Reyes, C., and Lopez, G. P. Common causes of glucose oxidase instability in in vivo biosensing: a brief review // J. Diabetes Sci. Technol. 2013. - No. 7. - P. 1030-1038.

18. Wang, B., Takahashi, S., Du, X., and Anzai, J. Electrochemical biosensors based on ferroceneboronic acid and its derivatives: a review. - Biosensors (Basel) 4. - 2014. - P. 243-256.

19. Gruhl, F. J., Rapp, B. E., and Lange, K. Biosensors for diagnostic applications // Adv. Biochem. Eng. Biotechnol. - 2013. - No. 133. - P. 115-148.

20. Guo, X. Single-molecule electrical biosensors based on single-walled carbon nanotubes // Adv. Mater. - 2013. - No. 25. - P. 3397-3408.

21. Ogi, H. Wireless-electrodeless quartz-crystalmicrobalance biosensors for studying interactions among biomolecules: a review // Proc. Jpn. Acad. Ser. B Phys. Biol. Sci. - 2013. - No. 89. - P. 401-417.

22. Peng, F., Su, Y., Zhong, Y., Fan, C., Lee, S. T., and He, Y. Silicon nanomaterials platform for bioimaging, biosensing, and cancer therapy // Acc. Chem. Res. 2014. - No. 47. - P. 612-623.

23. Shen, M. Y., Li, B. R., and Li, Y. K. Silicon nanowire field-effect-transistor based biosensors: from sensitive to ultra-sensitive // Biosens. Bioelectron. - 2014. No. 60. - P. 101-111.

24. Schneider, E., and Clark, D. S. Cytochrome P450 (CYP) enzymes and the development of CYP biosensors // Biosens. Bioelectron. - 2013. - No. 39. - P. 1-13.

25. Dias, A. D., Kingsley, D. M., and Corr, D. T. Recent advances in bioprinting and applications for biosensing // Biosensors (Basel). - 2014. - No. 4. - P. 111-136.

26. Khimji, I., Kelly, E. Y., Helwa, Y., Hoang, M., and Liu, J. Visual optical biosensors based on DNA-functionalized polyacrylamide hydrogel // Methods. - 2013. No. 64. - P. 292-298.

27. Kwon, S. J., and Bard, A. J. DNA analysis by application of Pt nanoparticle electrochemical amplification with single label response // J. Am. Chem. Soc. - 2012. No. 134. - P. 10777-10779.

28. Li, M., Li, R., Li, C. M., and Wu, N. Electrochemical and optical biosensors based on nanomaterials and 
nanostructures: a review. - Front. Biosci. (Schol Ed) 3, 2011. - P. 1308-1331.

29. Zhou, Y., Chiu, C. W., and Liang, H. Interfacial structures and properties of organic materials for biosensors: an overvie // Sensors (Basel). - 2012. No. 12. - P. 15036-15062.

30. Ko, P. J., Ishikawa, R., Sohn, H., and Sandhu, A. Porous silicon platform for optical detection of functionalized magnetic particles biosensing // J. Nanosci. Nanotechnol. - 2013. - No. 13. - P. 2451-2460.

31. Senveli, S. U., and Tigli, O. Biosensors in the small scale: methods and technology trends // IET Nanobiotechnol. - 2013. - No. 7. - P. 7-21.

32. Valentini, F., Galache, F. L., Tamburri, E., and Palleschi, G. Single walled carbon nanotubes/polypyrrole-GOx composite films to modify gold microelectrodes for glucose biosensors: study of the extended linearity // Biosens. Bioelectron. - 2013. - No. 43. - P. 75-78.

33. Lamprecht, C., Hinterdorfer, P., and Ebner, A. Applications of biosensing atomic force microscopy in monitoring drug and nanoparticle delivery // Expert. Opin. Drug Deliv. - 2014. - No. 11. - P. 1237-1253.

34. Hutter, E., and Maysinger, D. Gold-nanoparticle-based biosensors for detection of enzyme activity // Trends Pharmacol. Sci. - 2013. - No. 34. - P. 497-507.

35. Su, L., Jia, W., Hou, C., and Lei, Y. Microbial biosensors: a review // Biosens. Bioelectron. - 2011. - No. 26. P. 1788-1799.

36. Ding, L., Bond, A. M., Zhai, J., and Zhang, J. Utilization of nanoparticle labels for signal amplification in ultrasensitive electrochemical affinity biosensors: a review // Anal. Chim. Acta. - 2013. - No. 797. - P. 1-12.

37. Nie, S., Xing, Y., Kim, G. J., and Simons, J. W. Nanotechnology applications in cancer. Annu. Rev. // Biomed. Eng. - 2007. - No. 9. - P. 257-288.

38. Jain, R. K. Normalizing tumor microenvironment to treat cancer: bench to bedside to biomarkers // J. Clin. Oncol. - 2013. - No. 31. - P. 2205-2218.

39. Kunzelmann, S., Solscheid, C., and Webb, M. R. Fluorescent biosensors: design and application to motor proteins // EXS. - 2014. - No. 105. - P. 25-47.

40. Oldach, L., and Zhang, J. Genetically encoded fluorescent biosensors for live-cell visualization of protein phosphorylation // Chem. Biol. - 2014. - No. 21. - P. 186-197.

41. Randriamampita, C., and Lellouch, A. C. Imaging early signaling events in $\mathrm{T}$ lymphocytes with fluorescent biosensors // Biotechnol. J. - 2014. - No. 9. - P. 203-212.

42. De, M. R., Carimi, F., and Frommer, W. B. Mitochondrial biosensors. Int. // J. Biochem. Cell Biol. - 2014. No. 48. - P. 39-44.

43. Su, T., Zhang, Z., and Luo, Q. Ratiometric fluorescence imaging of dual bio-molecular events in single living cells using a new FRET pair mVenus/ mKOkappa-based biosensor and a single fluorescent protein biosensor // Biosens. Bioelectron. - 2012. - No. 31. - P. 292-298.
44. Johnson, B. N., and Mutharasan, R. Biosensor-based microRNA detection: techniques, design, performance, and challenges // Analyst. - 2014. - No. 139. - P. 15761588.

45. Park, K., Jung, J., Son, J., Kim, S. H., and Chung, B. H. Anchoring foreign substances on live cell surfaces using Sortase A specific binding peptide // Chem. Commun. (Camb) - 2013. - No. 49. - P. 9585-9587.

46. Du, Z., Li, H., and Gu, T. A state of the art review on microbial fuel cells: a promising technology for wastewater treatment and bioenergy // Biotechnol. Adv. - 2007. - No. 25. - P. 464-482.

47. Sun, J. Z., Peter, K. G., Si, R. W., Zhai, D. D., Liao, Z. H., Sun, D. Z., et al. Microbial fuel cell-based biosensors for environmental monitoring: a review // Water Sci. Technol. - 2015. - No. 71. - P. 801-809.

48. Gutierrez, J. C., Amaro, F., and Martin-Gonzalez, A. Heavy metal wholecell biosensors using eukaryotic microorganisms: an updated critical review // Front. Microbiol. - 2015. - No. 6. - P. 48.

49. Scheller, F. W., Yarman, A., Bachmann, T., Hirsch, T., Kubick, S., Renneberg, R., et al. Future of biosensors: a personal view // Adv. Biochem. Eng. Biotechnol. 2014. - No. 140. - P. 1-28.

50. Wang, S., Poon, G. M., and Wilson, W. D. Quantitative investigation of protein-nucleic acid interactions by biosensor surface plasmon resonance // Methods Mol. Biol. - 2015. - No. 1334. - P. 313-332.

\section{References.}

1. Mehrotra P. (2016). Biosensors and their applications - a review. Journal of Oral Biology and Craniofacial Research, vol. 6, no. 2, pp. 153-159.

2. Jiang X., Spencer M. G. (2010). Electrochemical impedance biosensor with electrode pixels for precise counting of CD4+ cells: A microchip for quantitative diagnosis of HIV infec- tion status of AIDS patients. Biosensors and Bioelectronics, vol. 25, no. 7, p. 1622-1628.

3. Luppa P. B., Sokoll L. J., Chan D. W. (2001). Immunosensors principles and applications to clinical chemistry. Clinica Chimica Acta, vol. 314, no. 1, p. 1-26.

4. Lee E. A. (2008). Cyber physical systems: Design challenges. Center for Hybrid and Embedded Software Systems, EECS University of California, Berkeley, CA 94720, USA, Tech. Rep. UCB/EECS-2008-8. Available at: https://www2.eecs.berkeley.edu/Pubs/ TechRpts/2008/ EECS-2008-8.pdf.

5. Lee J., Bagheri B., Kao H.-A. (2015). A cyberphysical systems architecture for industry 4.0-based manufacturing system. Manufacturing Letters, vol. 3, p. 18-23, ISSN: 2213-8463. Available at: http://www.sciencedirect.com/science/ article/pii/ S221384631400025X.

6. Berger C., Hees A., Braunreuther S., and Reinhart G. (2016). Characterization of cyber-physical sensor 
system. Procedia CIRP, vol. 41, p. 638-643. Available at: https://doi.org/10.1016/j.procir. 2015.12.019.

7. Martsenyuk V.P., Klos-Witkowska A., Sverstiuk A.S. (2018). Study of classification of immunosensors from viewpoint of medical tasks. Medical informatics and engineering. 1 (41). P. 13-19.

8. Martsenyuk V.P., Klos-Witkowska A., Sverstiuk A.S., Bihunyak T.V. (2018). On principles, methods and areas of medical and biological application of optical immunosensors. Medical informatics and engineering. 2 (42), p. 28-36.

9. Stability, bifurcation and transition to chaos in a model of immunosensor based on lattice differential equations with delay (2018). / V. Martsenyuk, A. Kłos-Witkowska, A. Sverstiuk. Electronic Journal of Qualitative Theory of Differential Equations. no. 27, pp. 1-31. doi: 10.14232/ ejqtde. 2018.1.27. [Online]. Available: https://doi. org/10.14232/ ejqtde.2018.1.27.

10. On modelling predator-prey cellular automaton with help of lattice differential equations with time dilay (2018). / V. Martsenyuk, A. Klos-Witkowska, A. Sverstiuk, O. Bagrii-Zayats, M. Bernas. Advances in biotechnology. 18th International Multidisciplinary Scientific GeoConference SGEM 2018. Nano, bio, green and space technologies for a sustainable, 2th-8th of July, Albena, Bulgaria. V. 18, ISSUE 6.2, p.407-414.

11. Byely`x I.A., Kleshhev M.F. (2011). Navchal`ny`j posibny`k „Biologichni ta ximichni sensorni sy`stemy ”. Xarkiv NTU «XPI», 143.

11. Turner, A. P. (2013). Biosensors: sense and sensibility. Chem. Soc. Rev. 42, 3184-3196. doi:10.1039/ c3cs35528d.

12. Citartan, M., Gopinath, S. C., Tominaga, J., and Tang, T. H. (2013). Label-free methods of reporting biomolecular interactions by optical biosensors. Analyst 138, 35763592. doi:10.1039/c3an36828a.

13. Sang, S., Wang, Y., Feng, Q., Wei, Y., Ji, J., and Zhang, W. (2015). Progress of new label-free techniques for biosensors: a review. Crit. Rev. Biotechnol. 15, 1-17. doi:10.3109/07388551.2014.991270.

15. Vigneshvar S., Sudhakumari C. C., Senthilkumaran Balasubramanian, Prakash Hridayesh Recent Advances in Biosensor Technology for Potential Applications - An Overview Frontiers in Bioengineering and Biotechnology, Volume 4. 2016 P. 11. ISSN=2296-4185 DOI=10.3389/fbioe.2016.00011.

16. Clark, L. C. Jr., and Lyons, C. (1962). Electrode systems for continuous monitoring in cardiovascular surgery. Ann. N. Y. Acad. Sci. 102, 29-45. doi:10.111 1/j.17496632.1962.tb13623.x

17. Harris, J. M., Reyes, C., and Lopez, G. P. (2013). Common causes of glucose oxidase instability in in vivo biosensing: a brief review. J. Diabetes Sci. Technol. 7, 1030-1038.

18. Wang, B., Takahashi, S., Du, X., and Anzai, J. (2014). Electrochemical biosensors based on ferroceneboronic acid and its derivatives: a review. Biosensors (Basel) 4, 243-256. doi:10.3390/bios4030243.

19. Gruhl, F. J., Rapp, B. E., and Lange, K. (2013). Biosensors for diagnostic applications. Adv. Biochem. Eng. Biotechnol. 133, 115-148. doi:10.1007/10_2011_130.

20. Guo, X. (2013). Single-molecule electrical biosensors based on single-walled carbon nanotubes. Adv. Mater. 25, 3397-3408. doi:10.1002/ adma.201301219.

21. Ogi, H. (2013). Wireless-electrodeless quartz-crystalmicrobalance biosensors for studying interactions among biomolecules: a review. Proc. Jpn. Acad. Ser. B Phys. Biol. Sci. 89, 401-417. doi:10.2183/pjab.89.401.

22. Peng, F., Su, Y., Zhong, Y., Fan, C., Lee, S. T., and He, Y. (2014). Silicon nanomaterials platform for bioimaging, biosensing, and cancer therapy. Acc. Chem. Res. 47, 612-623. doi:10.1021/ar400221g.

23. Shen, M. Y., Li, B. R., and Li, Y. K. (2014). Silicon nanowire field-effect-transistor based biosensors: from sensitive to ultra-sensitive. Biosens. Bioelectron. 60, 101-111. doi:10.1016/j.bios.2014.03.057.

24. Schneider, E., and Clark, D. S. (2013). Cytochrome P450 (CYP) enzymes and the development of CYP biosensors. Biosens. Bioelectron. 39, 1-13. doi:10.1016/j. bios.2012.05.043.

25. Dias, A. D., Kingsley, D. M., and Corr, D. T. (2014). Recent advances in bioprinting and applications for biosensing. Biosensors (Basel) 4, 111-136. doi:10.3390/ bios4020111.

26. Khimji, I., Kelly, E. Y., Helwa, Y., Hoang, M., and Liu, J. (2013). Visual optical biosensors based on DNAfunctionalized polyacrylamide hydrogels. Methods 64, 292-298. doi:10.1016/j.ymeth.2013.08.021.

27. Kwon, S. J., and Bard, A. J. (2012). DNA analysis by application of Pt nanoparticle electrochemical amplification with single label response. J. Am. Chem. Soc. 134, 10777-10779. doi:10.1021/ja304074f.

28. Li, M., Li, R., Li, C. M., and Wu, N. (2011). Electrochemical and optical biosensors based on nanomaterials and nanostructures: a review. Front. Biosci. (Schol Ed) 3:1308-1331. doi:10.2741/228.

29. Zhou, Y., Chiu, C. W., and Liang, H. (2012). Interfacial structures and properties of organic materials for biosensors: an overview. Sensors (Basel) 12, 1503615062. doi:10.3390/s121115036.

30. Ko, P. J., Ishikawa, R., Sohn, H., and Sandhu, A. (2013). Porous silicon platform for optical detection of functionalized magnetic particles biosensing. J. Nanosci. Nanotechnol. 13, 2451-2460. doi:10.1166/ jnn.2013.7406.

31. Senveli, S. U., and Tigli, O. (2013). Biosensors in the small scale: methods and technology trends. IET Nanobiotechnol. 7, 7-21. doi:10.1049/ ietnbt.2012.0005.

32. Valentini, F., Galache, F. L., Tamburri, E., and Palleschi, G. (2013). Single walled carbon nanotubes/polypyrroleGOx composite films to modify gold microelectrodes 
for glucose biosensors: study of the extended linearity. Biosens. Bioelectron. 43, 75-78. doi:10.1016/j. bios.2012.11.019.

33. Lamprecht, C., Hinterdorfer, P., and Ebner, A. (2014). Applications of biosensing atomic force microscopy in monitoring drug and nanoparticle delivery. Expert. Opin. Drug Deliv. 11, 1237-1253. doi:10.1517/17425 247.2014.917078.

34. Hutter, E., and Maysinger, D. (2013). Gold-nanoparticlebased biosensors for detection of enzyme activity. Trends Pharmacol. Sci. 34, 497-507. doi:10.1016/j. tips.2013.07.002/

35. Su, L., Jia, W., Hou, C., and Lei, Y. (2011). Microbial biosensors: a review. Biosens. Bioelectron. 26, 17881799. doi:10.1016/j.bios.2010.09.005.

36. Ding, L., Bond, A. M., Zhai, J., and Zhang, J. (2013). Utilization of nanoparticle labels for signal amplification in ultrasensitive electrochemical affinity biosensors: a review. Anal. Chim. Acta 797, 1-12. doi:10.1016/j. aca.2013.07.035.

37. Nie, S., Xing, Y., Kim, G. J., and Simons, J. W. (2007). Nanotechnology applications in cancer. Annu. Rev. Biomed. Eng. 9, 257-288. doi:10.1146/annurev. bioeng.9.060906.152025.

38. Jain, R. K. (2013). Normalizing tumor microenvironment to treat cancer: bench to bedside to biomarkers. J. Clin. Oncol. 31, 2205-2218. doi:10.1200/ JCO.2012.46.3653.

39. Kunzelmann, S., Solscheid, C., and Webb, M. R. (2014). Fluorescent biosensors: design and application to motor proteins. EXS 105, 25-47. doi:10.1007/978-3-03480856-9_2.

40. Oldach, L., and Zhang, J. (2014). Genetically encoded fluorescent biosensors for live-cell visualization of protein phosphorylation. Chem. Biol. 21, 186-197. doi:10.1016/j.chembiol.2013.12.012.

41. Randriamampita, C., and Lellouch, A. C. (2014). Imaging early signaling events in T lymphocytes with fluorescent biosensors. Biotechnol. J. 9, 203-212. doi:10.1002/biot.201300195.
42. De, M. R., Carimi, F., and Frommer, W. B. (2014). Mitochondrial biosensors. Int. J. Biochem. Cell Biol. 48, 39-44. doi:10.1016/j.biocel.2013.12.014.

43. Su, T., Zhang, Z., and Luo, Q. (2012). Ratiometric fluorescence imaging of dual bio-molecular events in single living cells using a new FRET pair mVenus/ mKOkappa-based biosensor and a single fluorescent protein biosensor. Biosens. Bioelectron. 31, 292-298. doi:10.1016/j.bios.2011.10.034.

44. Johnson, B. N., and Mutharasan, R. (2014). Biosensorbased microRNA detection: techniques, design, performance, and challenges. Analyst 139, 1576-1588. doi:10.1039/c3an01677c.

45. Park, K., Jung, J., Son, J., Kim, S. H., and Chung, B. H. (2013). Anchoring foreign substances on live cell surfaces using Sortase A specific binding peptide. Chem. Commun. (Camb) 49, 9585-9587. doi:10.1039/ c3cc44753g.

46. Du, Z., Li, H., and Gu, T. (2007). A state of the art review on microbial fuel cells: a promising technology for wastewater treatment and bioenergy. Biotechnol. Adv. 25, 464-482. doi:10.1016/j.biotechadv.2007.05.004.

47. Sun, J. Z., Peter, K. G., Si, R. W., Zhai, D. D., Liao, Z. H., Sun, D. Z., et al. (2015). Microbial fuel cell-based biosensors for environmental monitoring: a review. Water Sci. Technol. 71, 801-809. doi:10.2166/wst.2015.035.

48. Gutierrez, J. C., Amaro, F., and Martin-Gonzalez, A. (2015). Heavy metal wholecell biosensors using eukaryotic microorganisms: an updated critical review. Front. Microbiol. 6:48. doi:10.3389/fmicb.2015.00048.

49. Scheller, F. W., Yarman, A., Bachmann, T., Hirsch, T., Kubick, S., Renneberg, R., et al. (2014). Future of biosensors: a personal view. Adv. Biochem. Eng. Biotechnol. 140, 1-28. doi:10.1007/10_2013_251.

50. Wang, S., Poon, G. M., and Wilson, W. D. (2015). Quantitative investigation of protein-nucleic acid interactions by biosensor surface plasmon resonance. Methods Mol. Biol. 1334, 313-332. doi:10.1007/9781-4939-2877-4_20. 